\title{
Plastination Technique in Laboratory Rats: an Alternative Resource for Teaching, Surgical Training and Research Development
}

\author{
Técnica de Plastinación en Ratas de Laboratorio: Un Recurso Alternativo para \\ la Enseñanza, Entrenamiento Quirúrgico y Desarrollo de la Investigación
}

\begin{abstract}
Nicolás Ernesto Ottone,******; Vanina Cirigliano"; Marianela Lewicki ${ }^{* * * *}$; Homero F. Bianchi*; Santiago Aja-Guardiola ${ }^{* * * * *}$; Rubén Daniel Algieri"; Mario Cantin ${ }^{* * *, * * * * * * *}$ \& Ramón Fuentes ${ }^{* *, * * * * * * * * * *}$
\end{abstract}

OTTONE, N. E.; CIRIGLIANO, V.; LEWICKI, M.; BIANCHI, H.; AJA-GUARDIOLA, S.; ALGIERI, R. D.; CANTIN, M \& FUENTES, R. Plastination technique in laboratory rats: An alternative resource for teaching, surgical training and research development. Int. J. Morphol., 32(4):1430-1435, 2014.

SUMMARY: Today, alternatives methods are developed for the use of laboratory animals for teaching, research and surgical training. In our work we present a novel alternative to the use of rats, by developing a technique of plastination at room temperature. High-quality rat preparations from the anatomical dissection point of view were obtained, in order to indefinitely preserve them dry, the thoracic and abdominal organs conserve its natural volume and shape, maintaining their texture and color. No odors or hassles and toxic vapors of conventional preserving agents were found. This technique allows the collection of dry, completely biosafe and durable specimens in a short time and with excellent quality. Plastination in laboratory rats complements undergraduate and postgraduate anatomy studies perfectly. Also, radiology and surgery may benefit from this technique.

KEY WORDS: Plastination; Room temperature; Laboratory animals; Rats.

\section{INTRODUCTION}

Working with animals in a laboratory requires a trained and experienced animal care staff, with knowledge of biosafety regulations, in order to handle them correctly, as they become a biological reagent. Well-trained and experienced personnel in both practical and theoretical aspects are essential to fulfilling with international ethics regulations regarding laboratory animal handling, including Russell and Burch's three R's (replacement, reduction and refinement). Every teaching or research institution must develop an internal certification, with normalized operating procedures and satisfying ethical and laboratory good practice principles, to develop a responsible attitude towards animal experimentation.

It is essential to know that specimen fixation is a risky process and that laboratory personnel should be trained in handling hazardous material. Plastination of laboratory animals allows for safe specimens but also significantly reduces exposition of laboratory personnel and graduate and postgraduate students to toxicity derived from preserving specimens in formalin or other preserving substances.

Plastination is an anatomical technique used to preserve biological material with educational and training purposes. It was developed by Professor Gunther von Hagens in Heidelberg, Germany, in 1977 (von Hagens, 1979; Bickley et al., 1981; von Hagens et al., 1987; Ottone, 2013). This technique consists in substituting tissue fluids (water and lipids) by polymers. Specimens do not lose apparently normal texture and color features, thus resulting in odorless, dry specimens that are highly durable. After the specimen has been impregnated, it becomes much more stable than frozen,

\footnotetext{
Plastination Laboratory, Institute of Morphology J.J. Naón, Faculty of Medicine, Universidad de Buenos Aires, Argentina.

** Plastination Laboratory, Faculty of Dentistry, Universidad de La Frontera, Temuco, Chile.

*** Doctoral Program in Morphological Sciences, Faculty of Medicine, Universidad de La Frontera, Temuco, Chile.

***** Department of Histology and Embryology, Faculty of Dentistry, Universidad de Buenos Aires, Argentina.

****** Plastination Laboratory, Faculty of Veterinary, Universidad Nacional Autónoma de México D.F., México.

****** Center of Research in Biomedical Science, Universidad Autónoma de Chile, Temuco, Chile.

******** CIMOFIR Research Center, Faculty of Dentistry, Universidad de La Frontera, Temuco, Chile.
} 
OTTONE, N. E.; CIRIGLIANO, V.; LEWICKI, M.; BIANCHI, H.; AJA-GUARDIOLA, S.; ALGIERI, R. D.; CANTIN, M \& FUENTES, R. Plastination technique in laboratory rats: An alternative resource for teaching, surgical training and research development. Int. J. Morphol., 32(4):1430-1435, 2014.

dehydrated, or paraffin-treated specimens. Additional benefits include keeping texture and cellular identity at a microscopic level (Tianzhong et al., 1998; Henry, 2007; Raoof et al., 2007).

Its use in animal models, allows overcoming some limitations with human parts and their availability or ethical and legal considerations involved (Riederer, 2014). Plastinated rodents may become an excellent resource for teaching as they allow consulting, practicing gripping and handling, acknowledging anatomical relations and features, establishing reference points for surgical maneuvers, endoscopic training, develop autopsy protocols, among other purposes (Stuart \& Henry, 2002; Latorre et al., 2007).

The objective of this paper was to describe and promote a room temperature plastination technique in rodents as a resource in teaching and research, in order to facilitate training of personnel involved in research with laboratory animals.

\section{MATERIAL AND METHOD}

Five Wistar rats of similar ages and weights were used. These were obtained from the animal facility located at Department of Histology and Embryology, Faculty of Dentistry, University of Buenos Aires (the protocol was approved by the Bioethics Committee of the Faculty of Dentistry, University of Buenos Aires). The animals were kept under a 12/12-hour light/dark cycle, with a temperature of $19-23^{\circ} \mathrm{C}$, relative humidity of $50 \%$. Drinking water and food were provided ad libitum. The rats were taken care of, and received analgesia, anesthesia, and euthanasia procedures following international human care of laboratory animals and recommendations of the animal protection code used at Faculty of Dentistry's animal care facility.

The rats were euthanized by intracardiac injection of $0.2 \mathrm{ml}$ of pentobarbital sodium euthanistic diphenyl hydantoin (Eutanyle, Laboratory Brower) with the animal previously anesthetized with a combination of xylazine 2\% (Kensol, König Laboratory) and 5\% ketamine (Ketamine 50, Holliday Laboratory) at a dose of $5 \mathrm{mg} / \mathrm{kg}$ xylazine and $50 \mathrm{mg} / \mathrm{kg}$ ketamine.

After euthanasia, we proceeded to dissection. The animal was placed in a supine position and a longitudinal thoraco-abdominal incision in the midline was performed. Then, two incisions in the upper and lower ends, perpendicular to the longitudinal incision was made, allowing a greater opening of the thoracic and abdominal cavities, in the specimens of both sexes.

The samples were first fixed in a 5\% formaldehyde solution and later placed in a pool with the same proportion of formalin for one week in order to prevent the specimenís putrefaction and autolysis, killing all bacteria and certain proteins that may remain after dehydration and lead to decomposition. Furthermore, this phase is basic because it makes the preparation solid and helps reducing shrinkage after plastination.

The plastination was performed at the Plastination Laboratory, Institute of Morphology J.J. Naon, Faculty of Medicine, Universidad de Buenos Aires, Argentina. Below, we describe the plastination technique developed:

Dehydration. This phase aims to replace the formaldehyde solution with an intermediary solvent, a water-miscible solvent, such as acetone. Dehydration at room temperature $\left(20^{\circ} \mathrm{C}\right)$ lasted 2 weeks. For this, the sample was placed in a container of the same size, fully immersed in acetone, taking cover by about $2 \mathrm{~cm}$ from the sample. Then, the samples were subjected to 2 baths with $100 \%$ of acetone. Also, for the first bath could be used a greater than $90 \%$ concentration of acetone (reusing previous acetone baths is possible). The purity was measured with an acetonometer. This stage at room temperature also allows the defatting of specimens.

Forced impregnation. This is the most important phase of the plastination process and should be carried out slowly. Forced impregnation extracts the intermediary solvent (acetone) from the cell's structure and the preparation's interstice and replaces it with silicone. This exchange process is due to the high vapor pressure of acetone against the low vapor pressure of the silicone-catalyst mixture, where the volatile intermediary in the preparation is continuously withdrawn by a vacuum pump, until it is completely removed, generating a pressure difference, allowing the polymer to enter into the preparation. In our case, the impregnation's speed is carefully adjusted by a controlled air addition into the vacuum pump via a bypass valve.

We have developed the forced impregnation in two phases: "active" and "passive". Active forced impregnation consists in generating vacuum in a continuous fashion, inside the vacuum chamber, through the action of a vacuum pump. The anatomic material is placed inside a compactsized plastic container, custom-made for the preparation, to avoid wasting silicone (Fig. 1). The mixture in which the preparation is immersed includes generic silicone and generic catalyst / chain extender in a 100:1 ratio. The 


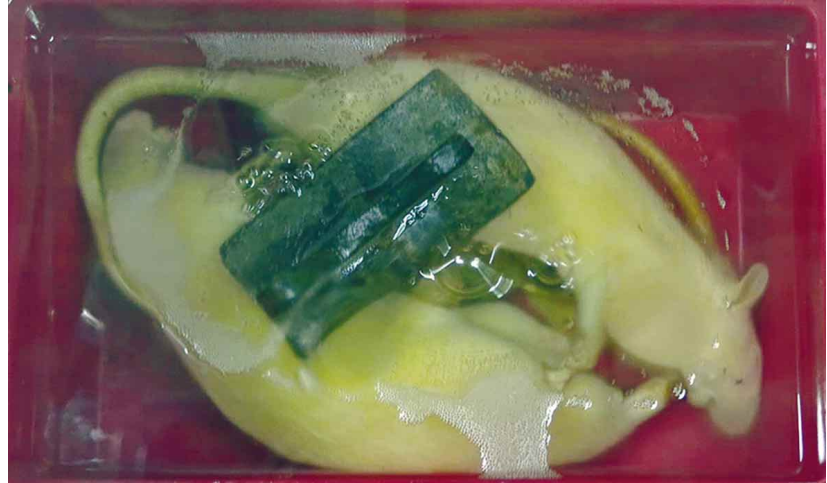

Fig. 1. Forced impregnation of two specimens inside the vacuum chamber.

preparation should be completely immersed in the mixture, using elements that keep it under. The whole vacuum process is carried out at room temperature. The pressure should be reduced by closing the valve (vacuum increases) until bubbling is observed. When bubbling occurs, pressure should be maintained so the process occurs at that pressure; that is, to keep bubbling by partially opening the valve. Bubbling is acetone vapor leaving the specimen and the silicone-catalyst mixture occupying the spaces left. Accurately, reducing the pressure to achieve greater vacuum, to reach the final goal of $5 \mathrm{mmHg}$, is not performed continuously. Instead, the preparation is under "active" forced impregnation during 8 hours each day. Once these 8 hours are completed, the vacuum chamber's valves are closed and the vacuum pump is switched off. The preparation is left inside the chamber, and the passive forced impregnation phase begins. This phase lasts until the next day when it starts again from the pressure at which the process was stopped before. Once the $5 \mathrm{mmHg}$ is reached and bubbling stops, the forced impregnation phase will be finished.

Draining. The preparation is removed from the siliconecatalyst mixture and left to drain in the same container to remove the excess silicone. Using paper to contribute to remove the silicone excess is also possible, and in the case of hollow entrails paper is placed inside cavities of the specimen to absorb silicone excess and help it dry. This can take two days, and depends on the size of the preparation. The time spent to drain was 7 days.

Positioning. Once the preparation has completely drained, we proceed to position the specimen's anatomical structures according to which section of the dissected region will be displayed. Positioning takes place at this time before the curing, when the specimen becomes hard and impossible to move.

Curing (polymerization). This process consists in the final curing and drying of the preparation. Silicone manages to stay inside the tissue. After removing the silicone excess, the specimen is placed inside a curing chamber and is exposed to the gas cure (generic hardener). It is placed inside a container and using a water tank engine, the hardener, that is liquid, starts bubbling until it is gasified. This acts upon the preparation, aiming at achieving the final drying and hardening of the preparation. It is important that the preparation is placed inside the curing chamber with silica crystals, which absorb moisture and keep the curing chamber interior dry. So there are two curing stages: fast and superficial curing, which takes 2-3 days, by exposing the specimen to the gas cure. This process achieves the external drying of the sample. However, during 3 or 4 months, the second stage starts: prolonged and internal curing. The specimen should be kept inside a plastic bag to achieve the final polymerization at the inner section of the preparation. Once this process ends, the specimen should be kept and stored at room temperature, with minimal care requirements.

\section{RESULTS}

The results are shown in Figures 2 and 3. The total time required to perform the technique was 32 days, divided as follows: 1 day for dissection, 14 days for drying, 5 days for forced impregnation, 7 days for draining excess silicone 5 days for polymerization of the specimens. In Table I, describes in detail the duration of forced impregnation.

All rats had the same size and weight, whereby the times of the technique were the same for all the specimens used. However, the time will vary in direct proportion to the size of the specimen, and especially during the process of forced impregnation. The larger the specimen, the higher the extent of impregnation time, extending in two or three days, always in the case of such specimens.

Drainage and polymerization times were also extended. The dehydration process is kept constant without changing by the size of the specimen.

Our proposal for an active and passive forced impregnation ensures the smooth incorporation of the mixture silicone-catalyst into the specimen, to avoid exaggerated and premature retraction of tissues, ensuring their original size and shape.

All rats were optimally plastinated, so we could get high-quality rats preparations from the anatomical dissection point of view in order to indefinitely preserve them dry, the thoracic and abdominal organs conserve its natural volume and shape, maintaining their texture and color. There was no difference in the final outcome by sex or weight. 


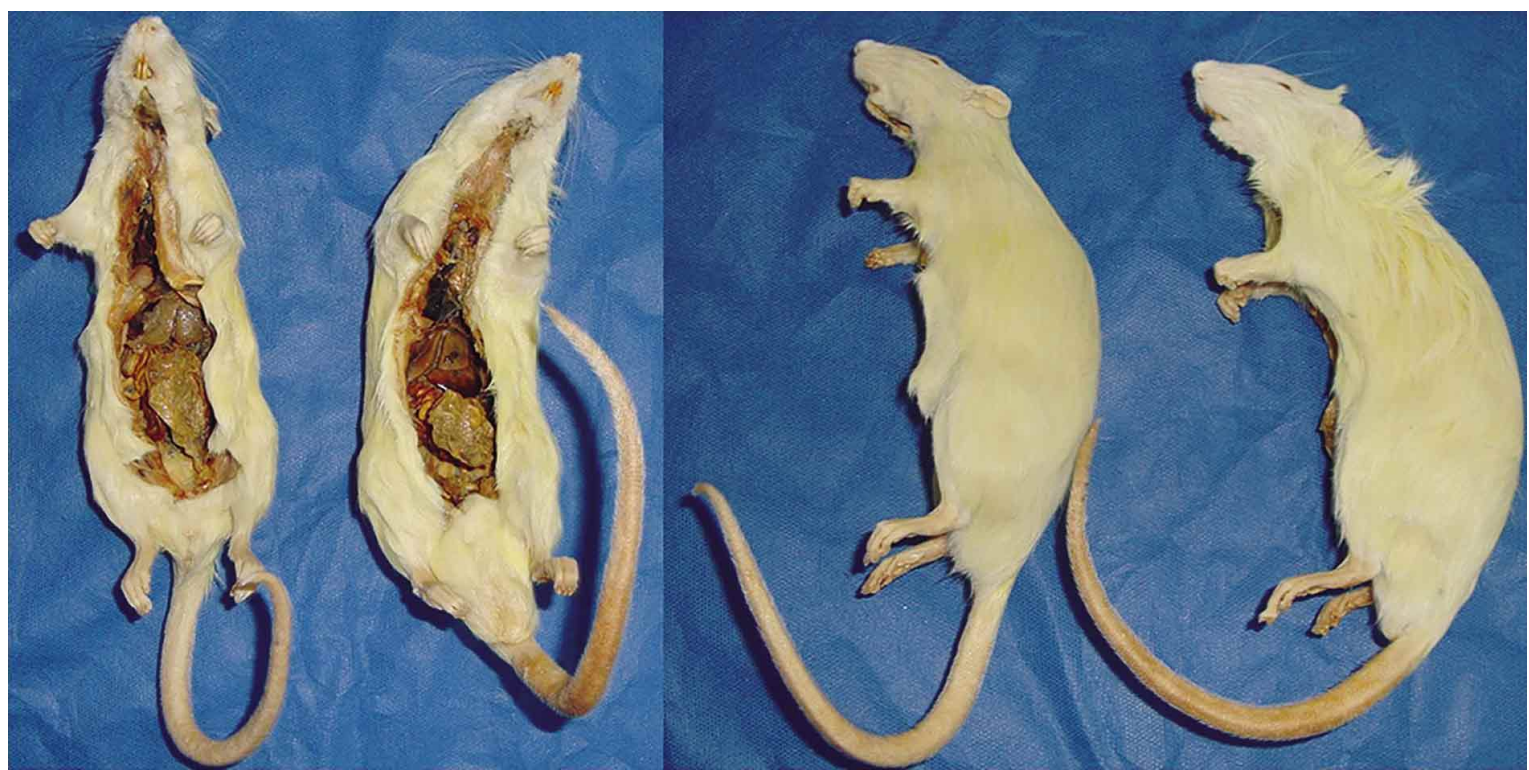

Fig. 2. Specimens after plastination, ready to be used. Abdominal organs are displayed.



Fig. 3. Another specimen (female rat) after plastination, positioned so that can stay on two legs for proper display of thoracic, abdominal and pelvic organs.

Table I. Forced impregnation process. This stage lasts for five days, in which periods of active forced impregnation ( $8 \mathrm{~h}$ each) and passive forced impregnation are combined (12 and 24 hours depending on the day). In this way it is sought to bring the pressure inside the vacuum chamber of $760 \mathrm{mmHg}$ to $5 \mathrm{mmHg}$, and in this final pressure, when the bubbles disappear, the forced impregnation process is over.

\begin{tabular}{lccc}
\hline Days & \multicolumn{2}{c}{ Active forced impregnation $(8 \mathrm{~h})$} & Pasive forced impregnation \\
\hline 1st day & --- & --- & $760 \mathrm{mmHg}(24 \mathrm{~h})$ \\
2nd day & $760 \mathrm{mmHg}$ & $460 \mathrm{mmHg}$ & $460 \mathrm{mmHg}(16 \mathrm{~h})$ \\
3rd day & $460 \mathrm{mmHg}$ & $160 \mathrm{mmHg}$ & $160 \mathrm{mmHg}(16 \mathrm{~h})$ \\
4th day & $160 \mathrm{mmHg}$ & $5 \mathrm{mmHg}$ & $760 \mathrm{mmHg}(24 \mathrm{~h})$ \\
5th day & --- & --- & $760 \mathrm{mmHg}(12 \mathrm{~h})$
\end{tabular}

No odors or hassles and highly toxic vapors of conventional preserving agents that are extremely toxic and irritating, such as formaldehyde and phenol were found. Manual handling and specimen resistance to handling are very convenient. 
OTTONE, N. E.; CIRIGLIANO, V.; LEWICKI, M.; BIANCHI, H.; AJA-GUARDIOLA, S.; ALGIERI, R. D.; CANTIN, M \& FUENTES, R. Plastination technique in laboratory rats: An alternative resource for teaching, surgical training and research development. Int. J. Morphol., 32(4):1430-1435, 2014.

\section{DISCUSSION}

The plastination technique using silicone at room temperature, described in this article, has allowed us to obtain high-quality specimens in a short period of time and at a low cost. This was achieved thanks to the local construction of the iron vacuum chambers and obtaining generics products, corresponding to silicone, catalyst and hardener. The lack of utilization of freezer not only cut the costs, but also contributed to the laboratory biosafety.

Handling biological material bear some risks regarding the specimen that will be preserved for dissection and anatomical examination, and the reagents used for fixating and preserving specimens. With this in mind, plastinated rodents are completely biosafe. This becomes essential if plastinated specimens are compared to samples preserved in the usual way. Plastinated samples are immersed in silicon, which is non-toxic and do neither release gases nor toxic substances. That is why they can be shown around in anatomy classes in pregraduate studies. The plastinated sample is a "friendlier" approach to cadaveric material. Visual impact of death on first-year students (quote authors) is less shocking than when specimens preserved in formalin are used, as formalin odor is not present, and plastinated specimens look more real.

The development of the plastination technique, as you may see in this work, achieves dry, odorless, durable, real, non-dangerous specimens that do not require maintenance and do not deteriorate with time. Another great advantage is that students and teachers may handle them without wearing gloves or following any safety measure. Museum specimens, preserved inside jars, are difficult / dangerous to manage. So are wet specimens preserved in formalin or in another preserving agent (Bickley et al., 1987; Dawson et al., 1990). This technique solves this issue.

Regarding maintenance of plastinated specimens, there is no need to use large pools with preserving agents, freezers, vacuum containers (Baptista et al., 1992). No other substances, techniques or devices are required. Plastinated samples are kept inside plastic bags and stored at room temperature $\left(20-22^{\circ} \mathrm{C}\right)$.

Regarding dissection activities, some authors think plastination may replace dissection of specimens. We, as well as other authors (Latorre et al.; Rieder), do not agree with this statement, plastination is not a replacement for traditional guided dissection, but it does provide an additional learning tool to understand complex anatomy. We consider plastinated specimens are to be used as a complement to dissection, if it can be done. Plastination may become useful for dissection students: they may first study anatomy and dissection planes in plastinated specimens and then dissect bodies more easily and safely.

Medical schools have started to show plastination not only as a basic tool for teaching and learning but also as a training and research method in postgraduate studies. The potential in plastination lies in its capacity for preserving delicate structures (Valenzuela et al., 2012), and its interrelations, including microscopic structures (Jones, 2002).

Besides this technique's advantages regarding biosafety, highly durable and low-maintenance samples, we have developed a plastination technique at room temperature that can be performed at a low cost, using local products and readily available equipment that any institution may acquire (Ottone et al., 2014). However, trained personnel are required to adequately carry out plastination.

In conclusion, plastination in laboratory rats complements pregraduate anatomy studies perfectly. Dry, odorless, completely biosafe and durable specimens are obtained. Anatomy, radiology and surgery may benefit from this technique. Postgraduate studies, for instance training in different surgical and dissection approaches, and morphological research activities also benefit from it.

OTTONE, N. E.; CIRIGLIANO, V.; LEWICKI, M.; BIANCHI, H.; AJA GUARDIOLA, S.; ALGIERI, R. D.; CANTIN, M \& FUENTES, R. Técnica de plastinación en ratas de laboratorio: Un recurso alternativo para la enseñanza, entrenamiento quirúrgico y desarrollo de la investigación. Int. J. Morphol., 32(4):1430-1435, 2014.

RESUMEN: En la actualidad, se desarrollan alternativas para el uso de animales de laboratorio para enseñanza, investigación y entrenamiento quirúrgico. En nuestro trabajo presentamos una novedosa alternativa para el uso de ratas, a través del desarrollo de una técnica de plastinación a temperatura ambiente. Se obtuvieron preparados de alta calidad desde el punto de vista de la disección anatómica, con órganos torácicos y abdominales que conservaron su volumen, forma, textura y color. Además, los especímenes carecen de olores y no emiten vapores tóxicos, debido a la ausencia de agentes conservantes convencionales. Esta técnica permite desarrollar especÌmenes secos de excelente calidad, completamente bioseguros y duraderos, en muy poco tiempo. La plastinación en ratas de laboratorio complementa los estudios de anatomía de pregrado y postgrado perfectamente. Además, las áreas de radiología y cirugía también pueden beneficiarse de esta técnica.

PALABRAS CLAVE: Plastinación; Temperatura ambiente; Animales de laboratorio; Ratas. 
OTTONE, N. E.; CIRIGLIANO, V.; LEWICKI, M.; BIANCHI, H.; AJA-GUARDIOLA, S.; ALGIERI, R. D.; CANTIN, M \& FUENTES, R. Plastination technique in laboratory rats: An alternative resource for teaching, surgical training and research development. Int. J. Morphol., 32(4):1430-1435, 2014

\section{REFERENCES}

Baptista, C. A. C.; Bellm, P.; Plagge, M. S. \& Valigosky, M. The use of explosion proof freezers in plastination: are they really necessary? J. Int. Soc. Plast., 6:34-37, 1992.

Bickley, H. C.; von Hagens, G. \& Townsend, F. M. An improved method for the preservation of teaching specimens. Arch. Pathol. Lab. Med., 105(12):674-6, 1981.

Bickley, H. C.; Walker, A. N.; Jackson, R. L. \& Donner, R. S. Preservation of pathology specimens by silicone plastination. An innovative adjunct to pathology education. Am. J. Clin. Pathol., 88(2):220-3, 1987.

Dawson, T. P.; James, R. S. \& Williams, G. T. Silicone plastinated pathology specimens and their teaching potential. J. Pathol., 162(3):265-72, 1990.

Henry, R. W. Silicone Plastination of Biological Tissue: Roomtemperature Technique North Carolina Technique and Products. J. Int. Soc. Plast., 22:26-30, 2007.

Jones, D. G. Re-inventing anatomy: the impact of plastination on how we see the human body. Clin. Anat., 15(6):436-40, 2002.

Latorre, R. M.; García-Sanz, M. P.; Moreno, M.; Hernández, F.; Gil, F.; López, O.; Ayala, M. D.; Ramírez, G.; Vázquez, J. M.; Arencibia, A. \& Henry R. W. How useful is plastination in learning anatomy? J. Vet. Med. Educ., 34(2):172-6, 2007.

Ottone, N. E. Gunther von Hagens, creator of Plastination. Historical Review and Technical Development. Rev. Arg. Anat. Onl., 4(2):70-6, 2013.

Ottone, N. E.; Cirigliano, V.; Bianchi, H. F.; Medan, C. D.; Algieri, R. D.; Borges Brum, G. \& Fuentes, R. New contributions to the development of a plastination technique at room temperature with silicone. Anat. Sci. Int., 2014. doi 10.1007/ s12565-014-0258-6

Riederer, B. M. Plastination and its importance in teaching anatomy. Critical points for long-term preservation of human tissue. $J$. Anat., 224(3):309-15, 2014.

Raoof, A.; Henry, R. W. \& Reed, B. Silicone Plastination of Biological Tissue: Room-temperature Technique Dow/ CorcoranTechnique and Products. J. Int. Soc. Plast., 22:21-5, 2007.

Stuart, M. D. \& Henry, R. W. Plastinated specimens can improve the conceptual quality of biology labs. Am. Biol. Teach., 64(2):130-4, 2002.

Tianzhong, Z.; Jingren, L. \& Kerming, Z. Plastination at room temperature. J. Int. Soc. Plast., 13(2):21-5, 1998.
Valenzuela, O. M.; Azocar, S. C.; Werner, F. K.; Vega, P. E. \& Valdés, G. F. Plastination Experience in Polyester Resin (P4). Int. J. Morphol., 30(3):810-3, 2012.

von Hagens, G. Impregnation of soft biological specimens with thermosetting resins and elastomers. Anat. Rec., 194(2):24755,1979

von Hagens, G.; Tiedemann, K. \& Kriz, W. The current potential of plastination. Anat. Embryol. (Berlin), 175(4):411-21, 1987.

\section{Correspondence to: \\ Prof. Nicolás Ernesto Ottone \\ Plastination Laboratory \\ Faculty of Dentistry \\ Universidad de La Frontera \\ Manuel Montt 112 \\ Temuco \\ CHILE}

Email: nicolas.ottone@ufrontera.c

Recibido : 18-08-2014

Aceptado: 22-09-2014 